\title{
“NOW IT'S MY RIGHTS VERSUS YOURS"» EQUALITY IN TENSION WITH RELIGIOUS FREEDOMS
}

\author{
JENA MCGILL*
}

This article focuses on cases involving the equality rights of gay, lesbian, bisexual, and queer people in tension with the religious freedoms of faith-based communities that denounce gay, lesbian, bisexual, and queer identities and same-sex intimacy. Part II focuses on the idea of rights in tension and considers the jurisprudence of competing rights, as well as the existing legal framework for reconciling conflicting Charter rights. Part III considers four appellate level religion-equality cases from the past 15 years. Part IV discusses the conflict of rights in these cases and their future implications.

\section{TABLE OF CONTENTS}

I. INTRODUCTION . . . . . . . . . . . . . . . . . . . . 583

II. THE JURISPRUDENCE OF RIGHTS IN TENSION . . . . . . . . . . . . . 586

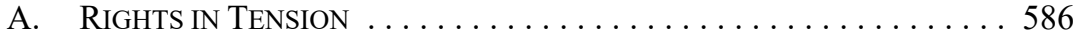

B. RECONCILING VERSUS BALANCING . . . . . . . . . . . 587

C. Four Core PrinciPLes . . . . . . . . . . . . . . . . . . . . . . . 589

III. RECONCILING EQUALITY AND RELIGION . . . . . . . . . . . . . . . . . . . . . 591

A. RECONCILING RELIGION AND EQUALITY: Four CASES . . . . . . . . 592

B. Shifting Approaches to Equality and Religion . . . . . . . . . 597

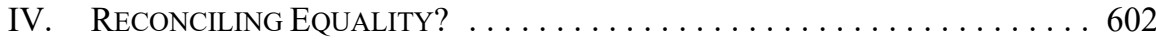

V. CONCLUSION ......................... 608

\section{INTRODUCTION}

In a 2002 article celebrating the first 20 years of the Canadian Charter of Rights and Freedoms, ${ }^{1}$ Justice Frank Iacobucci of the Supreme Court of Canada prophesized, "[ $t$ ]he task of reconciling Charter rights is challenging, and there can be little doubt but that difficult cases are on the horizon." Justice Iacobucci was right; claims that appear to pit individual rights guaranteed by the Charter and provincial human rights statutes against one another are increasingly at issue before Canadian courts and tribunals. These cases have required courts to adjudicate complicated contests between, for example, a sexual assault victim's right to privacy in medical and counselling records and an accused's right to full answer and defence; ${ }^{3}$ a child's right to life, liberty, and security of the person and her parents' right to

The title borrows from the lyrics of the song "My Rights Versus Yours" by Canadian indie rock band The New Pornographers, off the album Challengers (Matador Records, 2007) track 8.

Assistant Professor, University of Ottawa. An earlier version of this article was presented at the Emerging Issues in Public Law Conference at the University of Ottawa in May 2014. For helpful comments on the article, I am indebted to the attendees of the Emerging Issues event, to my colleague Vanessa MacDonnell and to two anonymous reviewers. I am also grateful to the Foundation for Legal Research for its support of this project, and to Suzie Dunn and Ani Mamikon for excellent research support.

1 Part I of the Constitution Act, 1982, being Schedule B to the Canada Act 1982 (UK), 1982, c 11 [Charter].

$2 \quad$ Frank Iacobucci, “The Charter: Twenty Years Later” (2002) 21 Windsor YB Access Just 3 at 31. $R v$ O'Connor, [1995] 4 SCR 411; $R$ v Mills, [1999] 3 SCR 668 [Mills]. 
freedom of religion; ${ }^{4}$ and a woman's religious right to wear a niqab while testifying in court and an accused's right to a fair trial. ${ }^{5}$

Rights reconciliation cases have moved from the horizon envisioned by Justice Iacobucci more than a decade ago to become a central, if not a defining, feature of the contemporary human rights landscape in Canada. As Barbara Hall, Chief Commissioner of the Ontario Human Rights Commission (OHRC) explains:

\begin{abstract}
At the Ontario Human Rights Commission we've seen more and more cases where rights protected by the Human Rights Code or the [Canadian] Charter of Rights conflict. It's hardly surprising. As our society changes, tensions can appear. Old ways brush up against new ones. Thankfully, more people are aware of their rights and are willing to protect and exercise those rights. But how to do the balancing act? ${ }^{6}$
\end{abstract}

Indeed, "institutions at the core of the Canadian human rights system - the courts and human rights commissions - are currently struggling to respond to the challenges presented by competing human rights claims in Canada."7 The regularity with which issues of competing rights are before courts and tribunals mandates engagement with a range of questions about the evolving legal doctrine of rights reconciliation and the results bred by the reconciling exercise in practice. How are reconciling rights cases impacting the content of individual rights guarantees? Does the reconciling exercise lead to consistent outcomes? What are the core principles according to which rights ought to be balanced when they come into conflict and are those principles reflected clearly in the jurisprudence?

Motivated by these global questions, this article focuses on one of the most challenging rights in tension scenarios: the growing lineage of cases situating the equality rights of gay, lesbian, bisexual, and queer (GLBQ) people ${ }^{8}$ against the religious freedoms of faith-based (predominately Christian) communities ${ }^{9}$ that denounce GLBQ identities and same-sex

$4 \quad B(R) v$ Children's Aid Society of Metropolitan Toronto, [1995] 1 SCR 315 [B (R)].

$R v N S, 2012$ SCC 72, [2012] 3 SCR 726 [NS].

Barbara Hall, "A most Canadian compromise: balancing free speech against other rights," The Globe \& Mail (28 February 2013), online: <www.theglobeandmail.com/globe-debate/a-most-canadiancompromise-balancing-free-speech-against-other-rights/article9146068/>.

7 Lorne Foster \& Lesley Jacobs, "Framing Competing Human Rights Claims: The Promise of Shared Social Citizenship" in Shaheen Azmi, Lorne Foster \& Lesley A Jacobs, eds, Balancing Competing Human Rights Claims in a Diverse Society: Institutions, Policy, Principles (Toronto: Irwin Law, 2012) 225 at 225 . See also The Honourable Justice Frank Iacobucci, "Reconciling Rights': The Supreme Court of Canada's Approach to Competing Charter Rights” (2003) 20 SCLR (2d) 137 [Iacobucci, "Reconciling Rights"] (arguing that "[w]hile much has been written on the limits of an individual's Charter rights vis-à-vis the state, the same cannot be said about the parameters of on individual's Charter rights vis-à-vis those of another" at 137).

8 I intentionally omit the category of trans people from this description because the majority of right in tension cases adjudicated in the past decade have involved rights related to sexual orientation (as opposed to gender identity), sexual identity, and same-sex behaviour. That the trans community and question of gender identity have been largely left out of this narrative is problematic: see e.g. Shannon Price Minter, "Do Transsexuals Dream of Gay Rights? Getting Real about Transgender Inclusion" in Paisley Currah, Richard M Juang \& Shannon Price Minter, eds, Transgender Rights (Minneapolis: University of Minnesota Press, 2006) 141.

9 The overwhelming majority of these cases involve the Christian Evangelical community, as noted by Miriam Smith, "Sexual Orientation and Religion in Canada: Litigation and Beyond" in Azmi, Foster \& Jacobs, supra note 7,349 at 351. Smith helpfully reminds that the distillation of the debate into a contest between "Christians" and "gay rights advocates" obscures the "multiple voices with different stances across a range of current policy issues" that animate both of these categories (ibid). While Christian Evangelicals have played a prominent role in litigation strategies against GLBQ rights, "adherents of other religious traditions have pursued other political strategies to block the recognition of LGBT rights or have intervened in court cases" (ibid). 
intimacy. Many have noted that "[t]he construction of rights in conflict and in need of balancing pervades the relationship of sexuality and religion," ${ }^{10}$ referring to this particular rights contest as the quintessential example of "[h]uman rights in gridlock with one another." 11 This "gridlock" shows few signs of easing up: Canada is in the midst of a protracted debate about how to reconcile the equality rights of sexual minorities and the religious rights of the Evangelical Christian community in the context of whether the Federation of the Law Societies, the government of British Columbia, and the provincial and territorial law societies should accredit a proposed Christian law school at Trinity Western University, which requires students, faculty, and staff to sign a mandatory Community Covenant promising to abstain from same-sex intimacy. ${ }^{12}$ I return to the particulars of this case below.

My purpose in this article is to consider how Canadian courts are reconciling tensions between religious rights and equality rights, using cases where the equality claim is based on the analogous ground of sexual orientation. In particular, I am interested in the shifting outcomes for equality rights in light of the fact that equality under section 15 of the Charter is notoriously amorphous and difficult to define, identify, and adjudicate, while the jurisprudence on religious rights guaranteed by section 2(a) is relatively more robust and consistent. Does the slipperiness of the Charter equality ideal inhibit reconciliation where it conflicts with more readily definable rights like religious freedoms? In considering this question, this article also serves as something of a retrospective, reflecting on how judicial treatment of the contentious rights contest between religion and equality based on sexual orientation has evolved over the life of the Charter.

The article begins in Part II by briefly unpacking the idea of rights in tension, and then looking to the jurisprudence of competing rights to outline the existing legal framework for reconciling competing Charter rights. In Part III, I hone in on the particulars of rights reconciliation in cases where religion and the equality rights of GLBQ people come into tension. This section uses four appellate level religion-equality cases from the past 15 years as case studies: the decision of the British Columbia Court of Appeal in Chamberlain v. Surrey School District \#36; ${ }^{13}$ the Supreme Court of Canada's decision in Trinity Western University v. British Columbia College of Teachers; ${ }^{14}$ the Court of Appeal for Saskatchewan's opinion in Reference re: Marriage Commissioners appointed under The Marriage Act, 1995 (Sask.); ${ }^{15}$ and the Supreme Court of Canada's recent decision in

Carl F Stychin, "Faith in the Future: Sexuality, Religion and the Public Sphere" (2009) 29:4 Oxford J Leg Stud 729 at 733.

$11 \quad$ Sarah Boesveld, "Gender vs religion: Woman refused haircut by Muslim barber highlights problem of colliding rights," National Post (30 November 2012) online: <news.nationalpost.com/2012/11/30/ gender-vs-religion-woman-refused-haircut-by-muslim-barber-highlights-problem-of-colliding-rights/>. Of course sexuality and religion are not by definition in conflict: see e.g. Patricia Hughes, "The Reconciliation of Legal Rights" in Azmi, Foster \& Jacobs, supra note 7, 271 [Hughes, "Reconciliation"]; Sean R Smallwood, “"Queerituality': Reforming What it Means to be a Religious Queer" (2015) 36 Vermont Connection 73; Ann Pellegrini, "Testimonial Sexuality; or, Queer Structures of Religious Feeling: Notes Towards an Investigation" (2005) 20:1 J of Dramatic Theory \& Criticism 93.

Trinity Western University, “Community Covenant Agreement," online: < twu.ca/ studenthandbook/twucommunity-covenant-agreement.pdf $>$ ["Covenant"].

2000 BCCA 519, 191 DLR (4th) 128 [Chamberlain CA].

2001 SCC 31, [2001] 1 SCR 772 [TWU SCC].

2011 SKCA 3, 327 DLR (4th) 669 [Marriage Commissioners]. 
Saskatchewan (Human Rights Commission) v. Whatcott. ${ }^{16}$ Part IV asks what the juxtaposition of these cases illustrates about judicial treatment of equality, religion, and the tension between the two, and queries the implications of these observations for future cases of equality rights in tension with religious freedoms and for competing Charter rights cases more broadly. ${ }^{17}$ In this final section, I point to the recent decision of the Nova Scotia Supreme Court in Trinity Western University v. Nova Scotia Barristers' Society as indicative of some of the ongoing challenges of reconciling equality and religion when the two are in tension. $^{18}$

\section{The JURisprudenCe OF Rights IN TENSION}

\section{A. Rights in Tension}

As a result of the increasing diversity of Canadian society, growing popular consciousness about human rights in the post-Charter era, and "Canadian constitutionalism's commitment to multiculturalism and the protection of plural cultural forms," 19 more and more cases in recent years have involved apparent contests or conflicts between individual rights guaranteed in the Charter or statutory human rights codes. ${ }^{20}$ Indeed, "conflicts among basic liberties are not anomalies, or rare hard cases. They are endemic in law and politics." ${ }^{21}$ These situations may be described as involving conflicts of rights, rights contests, competing rights or, borrowing from the work of Patricia Hughes, "rights in tension" with one another. ${ }^{22}$

Rights compete in many different ways: tensions may emerge within a single right, for example, between one claimant's right to equality based on religion and another claimant's right to equality based on sexual orientation; or the same claimant may find that relevant Charter rights seem to conflict within a single scenario, for example, where a terminally ill patient wishing to end his or her life finds that the right to life and rights to liberty or privacy counsel different outcomes depending on how the tension is resolved. ${ }^{23}$ The most common

2013 SCC 11, [2013] 1 SCR 467 [Whatcott SCC].

The focus of this article is on competing rights scenarios in the constitutional context, however the analysis bears relevance to similar cases that arise in the provincial and federal human rights systems. For specific treatment of competing rights in the provincial human rights context: see e.g. Shaheen Azmi, "Addressing Competing Human Rights Claims: The Policy Approach of the Ontario Human Rights Commission" in Azmi, Foster \& Jacobs, supra note 7, 97. 2015 NSSC 25, 381 DLR (4th) 296 [NSBS].

Benjamin L Berger, "Law's Religion: Rendering Culture" (2007) 45:2 Osgoode Hall LJ 277 at 279 [footnote omitted] (making this point in relation to the symbolic importance of the constitutional protection of religious liberties in particular). See also Hughes, "Reconciliation," supra note 11 (noting that Canada's character as "a secular and pluralist society based on a civic nationalism" explains in part the "major role" that rights in tension play in our country at 276 ).

This trend has been noted in other jurisdictions as well: see e.g. Eva Brems, "Introduction" in Eva Brems, ed, Conflicts Between Fundamental Rights (Oxford: Hart Publishing, 2008) 1 at 2; Emmanuelle Bribosia \& Isabelle Rorive, In search of a balance between the right to equality and other fundamental rights (Luxembourg: European Commission Directorate-General for Employment, Social Affairs and

Equal Opportunities, 2010) at 14.
John Gray, The Two Faces of Liberalism (Cambridge, UK: Polity Press, 2000) at 77.

Hughes, "Reconciliation," supra note 11 (according to Hughes, the term "rights in tension permits a more nuanced assessment of how rights interrelate with each other and with broader societal interests" as opposed to the more commonly used "competing" rights or "conflicting" rights which "set the stage for an adversarial process" where one right will trump the other(s) at issue at 273). See also Iacobucci, "Reconciling Rights," supra note 7 at 159-60 (finding the imagery of "clashing" or "conflicting" rights to be inappropriate descriptors of these kinds of cases, in part because the clash model suggests that two specific rights are inevitably in conflict, and belies the depth and complexity of the analysis undertaken to reconcile two apparently competing rights).

23 See e.g. the differing opinions in Rodriguez v British Columbia (Attorney General), [1993] 3 SCR 519. 
rights in tension scenario is what Lorenzo Zucca, in his typology classifying the various ways that rights and freedoms come into contest, terms an "external, inter-rights" conflict; that is, a conflict that involves two or more different rights or freedoms belonging to different individual rights-holders set in opposition to one another. ${ }^{24}$ This article focuses on these kinds of cases - situations where the facts at the heart of the dispute are framed in accordance with Zucca's “external, inter-rights" model of rights in tension. ${ }^{25}$

That fundamental rights can and will come into conflict with one another and require judicial resolution has been the subject of significant political and philosophical debate throughout the twentieth and twenty-first centuries. ${ }^{26}$ Many have argued that there can be no defining principle for resolving conflicting rights claims and intuition should guide the resolution of each unique circumstance, ${ }^{27}$ while others admit the inevitability of the emergence of a hierarchy of rights in liberal democracies, arguing that "[i]n order to resolve conflicts between basic liberties we must assess which liberty is most important. To do that we must consider their impact on society." 28 This debate has gradually extended to the legal realm, and courts and tribunals ${ }^{29}$ are now significant sites for teasing out the multidimensional question of how to conceptualize, analyze, and adjudicate rights in tension in Canadian society. ${ }^{30}$

\section{B. RECONCILING VERSUS BALANCING}

The general approach of Canadian courts to addressing cases of rights in tension is premised on the notion of reconciling or balancing rights. Although the two terms are often used interchangeably, Justice Iacobucci has drawn a distinction between the notion of "balancing," which suggests a weighing of rights to determine which one preponderates, and the idea of "reconciling," which aims to harmonize the rights in issue without preferring one

See generally Lorenzo Zucca, Constitutional Dilemmas: Conflicts of Fundamental Legal Rights in Europe and the USA (Oxford: Oxford University Press, 2007). For simplicity, I take as illustrative the scenario where two different claimants allege interference with two different rights, though of course there may be more than two rights implicated. See also Hughes, "Reconciliation," supra note 11 at 271-72; Ontario Human Rights Commission, Balancing Conflicting Rights: Towards and Analytical Framework (Toronto: OHRC, August 2005), online: <www.ohrc.on.ca/sites/default/files/attachments/ Balancing_conflicting_rights\%3A_Towards_an_analytical_framework.pdf $>$.

25 Zucca, ibid (Zucca's typology is helpful both for its revelation that not all rights conflicts are the same and, as a result, may require different approaches, and for illustrating how a single fact scenario involving rights in tension might be classified in a number of equally plausible ways each of which potentially gives rise to a different outcome).

26 Often these conflicts were historically framed in terms of specific rights claims, for example, the right to liberty and the right to equality. See e.g. John Rawls, A Theory of Justice (Cambridge, MA: Harvard University Press, 1971), who argued that in the case of conflicts some rights to basic liberties should have priority over others.

27 See e.g. Isaiah Berlin, Concepts and Categories: Philosophical Essays, ed by Henry Hardy (London, UK: Hogarth Press, 1978).

28 Gray, supra note 21 at 78. See also David M Brown, "Reconciling Equality and Other Rights: Paradigm Lost?" (2003) 15 NJCL 1 at 3.

29 See e.g. Gary Yee, "Competing Human Rights Claims during Tribunal Procedures" in Azmi, Foster \& Jacobs, supra note 7, 191.

Acknowledging that much of the contemporary discussion about balancing rights in Canada is centered on courts and thereby on litigation as the means by which balancing should occur, Smith, supra note 9 , argues quite rightly that "the cases that come to litigation do not necessarily reflect the diversity of tensions, conflicts and opinions around sexual orientation and religion ... [and] ... by focusing on litigation, we may concentrate too much on extremes in the debate, we may marginalize the views of other faith communities beyond Evangelical Protestantism, and we may ignore cases in which settlements among diverse stakeholders have been successfully reached" at 370-71. 
over the other. ${ }^{31}$ The distinction between "reconciling" and "balancing" further emphasizes an analytical division upheld by the Supreme Court between, on the one hand, rights in tension cases where as a threshold issue, courts will "define the content and scope of rights in relation to one another," 32 and, on the other hand, the exercise of balancing under section 1 of the Charter, where in assessing a government's attempt to justify an infringement of a Charter right pursuant to the framework established in $R v$. Oakes, ${ }^{33}$ a court must have reference to, inter alia, competing rights and "the underlying values and principles of a free and democratic society." 34 Many rights in tension cases have been resolved through the section 1 balancing framework, ${ }^{35}$ and the Supreme Court has "on numerous occasions stressed the advantages of reconciling competing rights by means of a s. 1 analysis." ${ }^{36}$ These advantages include the benefit of giving the broadest possible interpretation to the substance of Charter rights instead of formulating internal limits, and leaving to the relatively better resourced government the burden of justifying the limitations it has chosen in the context of a rights-infringing law, program, or activity. The Court has emphasized the flexibility and context specificity inherent in the Oakes analysis under section 1 as appropriate to the rights balancing exercise. ${ }^{37}$

Errol Mendes argues that although the Supreme Court maintains a distinction between reconciling rights through defining the scope of each in context and balancing rights under section 1 of the Charter, there is little meaningful difference between the two. In both circumstances the focus is on reaching a "contextual equilibrium" that puts "rights that seem to conflict into an equilibrium depending on what particular interests are at stake in any particular fact situation. ${ }^{, 38}$ For example, while Justice Iacobucci characterizes the Supreme Court's decision in $R$ v. Keegstra, ${ }^{39}$ a case engaging expressive rights and equality rights in the context of hate speech legislation - as "illustrative of the broad-based balancing that takes place under section 1" reconciling rights." ${ }^{41}$ While the mechanics of reconciling rights and balancing rights under section 1 may differ, the exercise of reconciling rights at the definitional stage and balancing rights at the section 1 stage share a common goal of identifying a context specific, nonhierarchical compromise position that allows the fullest possible realization of both rights in tension in the circumstances of the case.

\footnotetext{
$31 \quad$ Iacobucci, "Reconciling Rights," supra note 7. See e.g. Marriage Commissioners, supra note 15 at para 57 , referring to the section 1 exercise with the "reconciling" language. Iacobbuci, "Reconciling Rights," ibid at 141. [1986] 1 SCR 103 [Oakes].

Ibid at 136. The section 1 analysis includes consideration of:

[R] espect for the inherent dignity of the human person, commitment to social justice and equality, accommodation of a wide variety of beliefs, respect for cultural and group identity, and faith in social and political institutions which enhance the participation of individuals and groups in society. The underlying values and principles of a free and democratic society are the genesis of the rights and freedoms guaranteed by the Charter (ibid).

See e.g. B (R), supra note 4; Ross v New Brunswick School District No 15, [1996] 1 SCR 825 [Ross]. Multani v Commission scolaire Marguerite-Bourgeoys, 2006 SCC 6, [2006] 1 SCR 256 at para 26 [Multani].

See e.g. ibid; Ross, supra note 35 at paras 73-74; B (R), supra note 4 at 383-84.

Errol P Mendes, "Reaching Equilibrium between Conflicting Rights" in Azmi, Foster \& Jacobs, supra note 7,241 at 244.

[1990] 3 SCR 697 [Keegstra].

Iacobucci, "Reconciling Rights," supra note 7 at 143.

Mendes, supra note 38 at 245.
} 
Although Canadian courts consistently use "the language of balancing and accommodation, there is rarely any consideration of how this balancing would actually be undertaken in hard cases." 42 Accordingly, there is no exact formula to guide the process of reconciling in cases where rights are in tension. ${ }^{43}$ Instead, the Supreme Court has consistently proceeded from the broad statement "that clashes between rights should be approached by reconciling the rights through accommodation if possible, and in the end, if a conflict cannot be avoided, by case-by-case balancing" under section 1 of the Charter. ${ }^{44}$ The jurisprudence reveals four related principles intended to guide decision-makers when faced with rights in tension under the Charter.

\section{Four Core Principles}

First, the "golden rule" is an unwavering commitment to the principle that there can be no hierarchy of Charter rights. ${ }^{45}$ Courts must "give the fullest possible expression to all relevant Charter rights, having regard to the broader factual context and to the other constitutional

42 Stychin, supra note 10 at 749 [footnote omitted] [emphasis in original] (making this comment in respect of the Supreme Court jurisprudence related to religion and equality for sexual minorities). See also Whatcott, supra note 16 (Factum of the Intervener, Ontario Human Rights Commission) [OHRC Factum] where the Commission argues:

Despite the increased number and complexity of [rights in tension] situations, there is limited

jurisprudence addressing one person's claim that his or her rights are being detrimentally affected

by the assertion of another's rights. To date, decisions have established key principles, but little

by way of a concrete analytical approach to address rights in tension (ibid at para 4).

The Ontario Human Rights Commission has recently encouraged the Supreme Court to synthesize its jurisprudence on reconciling rights into a broadly applicable framework to guide decision makers: see Ontario Human Rights Commission, Police on competing human rights (Toronto: OHRC, 26 January 2012). For a similar initiative to establish guidelines and a methodology in the specific context of balancing rights to equality and non-discrimination with other fundamental rights in the European Union context, see e.g. Bribosia \& Rorive, supra note 20.

NS, supra note 5 at para 52. In Reference re: Same-Sex Marriage, 2004 SCC 79, [2004] 3 SCR 698 [Re: Same-Sex Marriage], the Supreme Court confirmed:

The first question is whether the rights alleged to conflict can be reconciled. Where the rights cannot be reconciled, a true conflict of rights is made out. In such cases, the Court will find a limit on [the claimant's Charter]freedom and go on to balance the interests at stake under s. 1 of the Charter. In both steps, the Court must proceed on the basis that the Charter does not create a hierarchy of rights (ibid at para 50 [citations omitted]).

The relevant framework will be slightly different when the conflict arises at common law. Recently, in NS, supra note 5, the Supreme Court extended principles first developed in the context of publication bans to establish four steps for "identifying and resolving rights conflicts that arise at common law" generally (ibid at para 7). In the context of NS, the Court applied the steps to reconcile an apparent conflict between the religious freedom of a witness to wear a niqab while testifying in court, and an accused's right to full answer and defense:

1. Would requiring the witness to remove the niqab while testifying interfere with her religious freedom?

2. Would permitting the witness to wear the niqab while testifying create a serious risk to trial fairness?

3. [If the answers to \#1 and \#2 are "yes"] Is there a way to accommodate both rights and avoid the conflict between them?

4. If no accommodation is possible, do the salutary effects of requiring the witness to remove the niqab outweigh the deleterious effects of doing so? (Ibid at para 9.) Declaration and Programme of Action, UNGAOR, UN Doc A/CONF.157/23 (1993) at art 5, online: UNOHCHR <www.ohchr.org/Documents/ProfessionalInterest/vienna.pdf>, which recognizes: "All human rights are universal, indivisible, interdependent and interrelated ... [and must be treated] in a fair and equal manner, on the same footing, and with the same emphasis." 
values at stake. ${ }^{\circ 6}$ In Dagenais, one of the first Supreme Court cases to address rights in tension in the context of publication bans, Chief Justice Lamer affirmed:

\begin{abstract}
A hierarchical approach to rights, which places some over others, must be avoided, both when interpreting the Charter and when developing the common law. When the protected rights of two individuals come into conflict.... Charter principles require a balance to be achieved that fully respects the importance of both sets of rights. $^{47}$
\end{abstract}

Second and closely related, no Charter right is absolute. An individual's rights are "inherently limited by the rights and freedoms of others," 48 and reconciliation requires "that no one right be regarded as inherently superior to another." 49 So, for example, freedom of expression has been limited where it causes harm to vulnerable members of society through pornography or hate speech. ${ }^{50}$ This means that a claimant's rights might not actually extend as far as he or she alleges, and it will be up to the court to determine, as a threshold issue under the reconciling framework, whether the alleged rights infringement in fact properly falls within the ambit of a protected Charter right.

Third, where rights are in tension, the resolution must have careful regard to the full context of the case, including the relevant facts and Charter principles. This means that rights contests cannot be resolved in the abstract. The "collision between rights must be approached on the contextual facts of actual conflicts" $" 51$ because the meaning and content of Charter rights "are not defined in abstraction, but rather in the particular factual matrix in which they arise." 52 In Re: Same-Sex Marriage, the Supreme Court concluded that the alleged conflict between freedom of religion and equality did not give rise to any actual conflict because the legislation in question had not yet been passed or implemented. The rights conflict alleged was purely speculative. The Court concluded that absent a factual context "it would be improper to assess whether the Proposed Act, if adopted, would create an impermissible collision of rights in as yet undefined spheres." ${ }^{\prime \prime 3}$

Fourth and finally, in a competing rights scenario, a court must, in the reconciliation exercise, have regard to the extent or severity of the interference with each right. This

Iacobucci, "Reconciling Rights," supra note 7 at 140. See also NS CA, ibid at para 48; Re: Same-Sex Marriage, supra note 44 at para 50.

$47 \quad$ Dagenais, supra note 45 at 877 . But see Mary Anne Waldron, Free to Believe: Rethinking Freedom of Conscience and Religion in Canada (Toronto: University of Toronto Press, 2013), who states:

$[\mathrm{I}] \mathrm{n}$ a human rights complaint or in a Charter action, there are at least two parties before the tribunal and they are arguing for mutually exclusive results. One of these results will normally be approved by the court. The situation does not admit of any form of compromise in the result because a court does not devise the remedy for the parties in isolation from or in opposition to what the parties themselves have requested. The court (or human rights tribunal) simply picks one of the solutions before it and, as noted, that solution will exclude the solution for which the other party has argued (ibid at 165 [footnote omitted]).

$P(D)$ v S (C), [1993] 4 SCR 141 at 182, L'Heureux-Dubé J concurring.

NS CA, supra note 45 at para 48 . See also Mills, supra note 3.

See e.g. $R \vee$ Butler, [1992] 1 SCR 452 [Butler]; $R$ v Sharpe, 2001 SCC 2, [2001] 1 SCR 45; Keegstra, supra note 38.

Re: Same-Sex Marriage, supra note 44 at para 50.

52 Iacobucci, "Reconciling Rights," supra note 7 at 141 , cited in NS CA, supra note 45 at para 48 . See also Mills, supra note 3 at para 21; MacKay v Manitoba, [1989] 2 SCR 357 ("Charter decisions should not and must not be made in a factual vacuum. To attempt to do so would trivialize the Charter and inevitably result in ill-considered opinions. The presentation of facts is not ... a mere technicality; rather, it is essential to a proper consideration of Charter issues" at 361). 
principle is a natural extension of the importance placed on context in the rights reconciliation exercise - it is only with full regard to the facts, including the seriousness of the interference with each right in the circumstances at hand, that true reconciliation can take place. This means that where the conduct at issue "is at the 'periphery' of a right, it is more likely to be required to give way to a right whose core values are engaged." ${ }^{54}$ In some cases, like the recent decision in NS, this assessment may involve "weighing the competing harms" to each of the rights at stake. ${ }^{55}$

Based on these four principles, the reconciliation approach "reflects a pluralist view of Canadian society in which there is recognition of the complexity of interests and claims, which is characterized by a system of values transcending individual rights and which provides a way by which all citizens can access these rights." ${ }^{56}$ The reconciliation exercise is cast in broad terms and assumes any contest between Charter rights can be resolved through the proper application of the relevant principles. ${ }^{57}$ I turn now to focus on the particularities of this exercise in practice when the rights at issue are the equality based on sexual orientation and religious freedoms under the Charter.

\section{RECONCILING EQUALITY AND RELIGION}

As noted above, the rights conflict between freedom of religion guaranteed by section 2(a) of the Charter and the equality rights of GLBQ people protected by section 15 presents one of the most controversial and challenging issues in our contemporary human rights landscape. The relevant Charter language provides:

2. Everyone has the following fundamental freedoms:

(a) freedom of conscience and religion;

15. (1) Every individual is equal before and under the law and has the right to the equal protection and equal benefit of the law without discrimination and, in particular, without discrimination based on race, national or ethnic origin, colour, religion, sex, age or mental or physical disability.

(2) Subsection (1) does not preclude any law, program or activity that has as its object the amelioration of conditions of disadvantaged individuals or groups including those that are disadvantaged because of race, national or ethnic origin, colour, religion, sex, age or mental or physical disability. ${ }^{58}$

As Miriam Smith explains, "[w]hile the last fifteen years have seen a significant expansion of LGBT rights, there have also been significant tensions over the status of religious rights

54 OHRC Factum, supra note 42 at para 32 [footnote omitted]. Supra note 5 at para 81 , Abella J, dissenting.

Hughes, "Reconciliation," supra note 11 at 277-78 [footnote omitted].

Some would contest the appropriateness of a global approach to reconciling rights: see e.g. Waldron, supra note 47 , and Zucca, supra note 24 , (both Waldron and Zucca challenge the assumption that courts can reconcile all kinds of rights contests across various contexts using the same tools). 
in relation to claims for protection from discrimination based on sexual orientation." ${ }^{, 59}$ The result is an increasing number of cases that engage questions about how to reconcile religious freedom and equality rights based on sexual orientation across various contexts. ${ }^{60}$ These cases are revealing for what they uncover about many of the foundational challenges and compromises that inevitably face Canada in negotiating the place of religious belief in a secular, pluralist, and increasingly multi-perspectival country. I do not engage these important broader questions here. ${ }^{61}$ Instead, this section focuses on the judicial treatment of religion-equality contests, relying on four appellate level cases where the equality interests of the GLBQ community came up against the religious freedoms of others to illustrate the various ways that courts have conceptualized religion, equality, and the conflict between the two.

Given the emphasis on context in reconciling rights scenarios, it is noteworthy that the contexts of the cases canvassed below differ in significant ways. Chamberlain SCC and TWU SCC involve judicial review of decisions made by administrative bodies, Marriage Commissioners is a provincial reference and Whatcott SCC involves a direct challenge to a provincial human rights statute. TWU SCC and Chamberlain SCC arise in the context of questions about the regulation of educational settings, Marriage Commissioners addresses the personal religious beliefs of marriage commissioners acting in their public capacity, and Whatcott SCC turns on the actions of a private individual disseminating his religious beliefs in the public realm.

\section{A. Reconciling Religion AND EQUALity: Four CASES}

\section{ChAMBERLAin V. SuRREy SCHOOL District No. 36}

In Chamberlain SCC, a teacher sought permission from the Surrey School Board (the Board) to use three books depicting same-sex families in his kindergarten and grade one classrooms. The Board refused to approve the books, citing concerns that "approval of the books would engender controversy in light of parents' views and might undermine the relationship between home and school." ${ }^{2}$ There was evidence that "at least one trustee who voted for the motion [to refuse the books], ... has campaigned for several years to promote a greater role for religion in governance of the community, including on the issue of homosexuality." ${ }^{63}$ Mr. Chamberlain sought judicial review of the Board's decision, arguing

$59 \quad$ Smith, supra note 9 at 350.

60 The importance of equality and the right to non-discrimination, and its role as an animating concept for other human rights has led to some limited discussion, primarily in the European context, about whether equality should take precedence over other rights and freedoms. This proposal has been largely rejected not only because it flies in the face of the principle that all rights are equal and no hierarchy of rights exists, but also because in establishing equality as the preeminent right, "equality itself becomes a world view which monopolizes the public sphere, as 'a certain paradox ensues in which the coerced adoption of certain cultural norms becomes a requisite for entry into a polity that defines itself as the avatar of freedom" (Stychin, supra note 10 at 733 citing Judith Butler, "Sexual politics, torture, and secular time" (2008) 59:1 British J Sociology 1 at 4). See also Bribosia \& Rorive, supra note 20 at 20-23 (noting the practical and philosophical difficulties with the idea of giving prominence to equality).

61 See e.g. Benjamin Berger, "The Limits of Belief: Freedom of Religion, Secularism and the Liberal State" (2002) 17:1 CJLS 39; Lori G Beaman, "Is Religious Freedom Impossible in Canada?" (2012) 8:2 L Culture \& Humanities 266.

62 Chamberlain v Surrey School District No 36, 2002 SCC 86, [2002] 4 SCR 710 at para 48 [Chamberlain $\mathrm{SCC}]$.

63 Chamberlain v School District \# 36 (Surrey) (1998), 168 DLR (4th) 222 at para 94 (BCSC) [Chamberlain SC]. 
that it infringed the Charter and was contrary to the British Columbia School Act, which provided that all schools subject to the Act "be conducted on strictly secular and nonsectarian principles" and required that "[ $\mathrm{t}]$ he highest morality must be inculcated, but no religious, dogma or creed is to be taught in a school." ${ }^{64}$ The British Columbia Supreme Court found that the decision of the Board to refuse the books was influenced by religious considerations and accordingly was contrary to the Act. ${ }^{65}$

A unanimous ruling of the British Columbia Court of Appeal overturned this decision. The Court of Appeal concluded that the "strictly secular" requirement in the Act could not be interpreted as limited to moral positions "devoid of religious influence." ${ }^{\prime 66}$ Characterizing the position taken by the Board trustees against the books depicting same-sex relationships as a moral one, the Court found that "in a truly free society moral positions advance or retreat in their influence on law and public policy through decisions of public officials who are not required to pass a religious litmus test." ${ }^{.67}$ The Court also declared that the term "highest morality" in the Act included the Charter value and "moral principle" against discrimination on the basis of sexual orientation. However, based on a directive issued by the Surrey Superintendent of Schools entitled "Tolerance for Sexual Orientation," the Court was satisfied that Board had adequately accounted for this principle, finding no "reason not to take this directive at its word or to conclude that the Board did not stand behind its admonition." 68

While I am interested in the Court of Appeal decision in Chamberlain for the purposes of this analysis, it is important to note that this decision was ultimately overturned by a majority of the Supreme Court of Canada. The Supreme Court concluded that while the requirement of secularism in the Act does not mean that religious considerations have no place in school board deliberations, the Board "cannot prefer the religious views of some people in its district to the views of other segments of the community. Nor can it appeal to views that deny the equal validity of the lawful lifestyles of some in the school community." ${ }^{\prime 9}$ The Board's decision was accordingly found to be outside the mandate of the School Act and could not stand. Justices Gonthier and Bastarche, in dissent, would have upheld the decision of the Court of Appeal, finding the Board's decision to be consistent with the Act and the Charter.

\section{2.}

TRINITY WESTERN UNIVERSITY

\section{BRITISH COLUMBIA COLLEGE OF TEACHERS}

TWU SCC involved an application by a Christian post-secondary education institution in Langley, British Columbia, to the British Columbia College of Teachers (BCCT) to have its teacher-training program certified so that its students could complete their entire program at

School Act, RSBC 1996, c 412, ss 76(1)-(2).

Chamberlain SC, supra note 63.

Chamberlain CA, supra note 13 at para 28. See also ibid (the Court of Appeal found that respect for a diversity of religious and non-religious beliefs and viewpoints in public schools, "precludes any religious establishment or indoctrination associated with any particular religion in the public schools but it cannot make religious unbelief a condition of participation in the setting of the moral agenda. Such a disqualification would be contrary to the fundamental freedom of conscience and religion set forth in s. 2 of the Charter, and the right to equality in s. 15 " at para 31 ).

Ibid at para 28 .

Ibid at para 39.

Chamberlain SCC, supra note 62 at para 25. 
Trinity Western University (TWU), rather than having to spend their final year at nearby Simon Fraser University. The BCCT rejected the request for approval on the basis that TWU's proposed program followed discriminatory practices, contrary to the public interest and public policy. BCCT's concerns stemmed from the requirement that TWU students sign the Covenant, which expressly prohibited "sexual sins including ... homosexual behavior." BCCT concluded that the Covenant gave rise to a reasonable risk that TWU graduates would discriminate on the basis of sexual orientation once they became teachers, putting the equality rights of public school students and families at risk. The decision of the BCCT was upheld on appeal to the BCCT's governing council, but overturned by the British Columbia Supreme Court and the British Columbia Court of Appeal on the basis that the BCCT had no reasonable basis for concluding that TWU teacher graduates would discriminate on the basis of sexual orientation in public school classrooms. ${ }^{70}$

The case reached the Supreme Court of Canada, where the majority disposed of the issue through the reconciliation framework, finding "the scope of the freedom of religion and equality rights that have come into conflict in this appeal can be circumscribed and thereby reconciled." The Court held that "[t]he freedom to hold beliefs is broader than the freedom to act on them",72 and characterized the Covenant as a simple expression of belief. "Absent concrete evidence that training teachers at TWU fosters discrimination in the public schools of B.C.," 73 permitting TWU to train public school teachers did not give rise to a serious risk that those teachers would act in a discriminatory fashion and thereby infringe equality interests. The BCCT's decision to deny TWU's application was classified as a serious infringement of that community's rights to religious freedom, "preventing them from expressing freely their religious beliefs and associating to put them into practice." ${ }^{\prime 74}$ The alleged conflict was reconciled out of existence because, absent evidence of discriminatory behaviour by TWU-trained teachers, the equality rights of the GLBQ community were simply not engaged on the facts of the case. ${ }^{75}$

\section{REFERENCE RE: MARRIAGE COMMISSIONERS APPOINTED UNDER THE MARRIAGE ACT, $1995^{76}$}

In Reference re: Saskatchewan Marriage Commissioners the Court of Appeal for Saskatchewan was asked to consider the constitutionality of proposed amendments to the provincial Marriage Act which would allow a civil marriage commissioner to refuse to solemnize same-sex marriages if doing so would be contrary to his or her religious beliefs. First, the Court determined: (BCSC); Trinity Western University v BC College of Teachers (1998), 169 DLR (4th) 234 (BCCA) [TWU CA].

TWU SCC, supra note 14 at para 37.

Ibid at para 36 .

Ibid.

Ibid at para 32 .

There were strong dissenting opinions about the discriminatory effect of the Covenant at both the British Columbia Court of Appeal (TWU CA, supra note 70 at para 220, Rowles JA, dissenting) and the Supreme Court of Canada (TWU SCC, supra note 14 at para 72, L'Heureux-Dubé J, dissenting). The Marriage Act, 1995, SS 1995, c M-41 [Marriage Act]. 
[This case is] concerned with managing the intersection of the freedom of religion of marriage commissioners on the one hand, and the equality rights of gay and lesbian individuals on the other. Both interests are guaranteed by the Charter and this is not a situation where th[e] potential conflict [between religious rights and equality rights] can be resolved through the way in which the scope of either s. 2(a) or s. 15(1) of the Charter is delineated. As a consequence, their accommodation or balancing must be conducted by resort to $\mathrm{s} .1$ of the Charter. ${ }^{77}$

The Court of Appeal concluded that the proposed amendments amounted to a violation of the section 15 equality rights of gay and lesbian individuals, characterizing the impact on same-sex couples of being told by a marriage commissioner that he or she will not solemnize a same-sex union as "genuinely offensive" 78 and "perpetuat[ing] disadvantage and ... stereotypes about the worthiness of same-sex unions.",79

The Court then turned to balancing the competing rights according to the section 1 analysis laid out in Oakes. The Court determined the pressing and substantial objective of the amendments to be "the accommodation of the s. 2(a) Charter freedoms of [marriage] commissioners by relieving them of the obligation to perform marriage ceremonies in circumstances where doing so would be contrary to their religious beliefs." rational connection between this objective and permitting marriage commissioners to opt out of solemnizing same-sex marriage in the name of their religious beliefs, but the proposed amendments were not minimally impairing because there were other ways to accommodate the religious beliefs of marriage commissioners while impinging less seriously on the equality rights of same-sex couples. ${ }^{81}$ The salutary effects of the amendments would "allow marriage commissioners to avoid acting in situations which would offend their religious beliefs," 82 however they were outweighed by the deleterious effects of the law, including the negative impacts on the couples denied marriage services and on the broader societal commitment to equality. The Court concluded that this was "one of those situations where religious freedom must yield to the larger public interest." ${ }^{83}$ The government's proposed amendments were deemed unconstitutional.

\section{SASKATCHEWAN HUMAN RightS COMMISSION V. WHATCOTT}

The 2013 decision in Whatcott SCC is the most recent case from the Supreme Court of Canada addressing contests between religion and the equality of GLBQ individuals in the constitutional context. Mr. Whatcott, who campaigns against homosexuality on the basis that it is contrary to his religious beliefs, published and distributed a series of flyers targeting gay

Marriage Commissioners, supra note 15 at para 66 [citations omitted].

Ibid at para 41 .

Ibid at para 45 .

Ibid at para 76 .

Ibid at para 88. The main alternative considered was a system whereby a couple seeking the services of a marriage commissioner would proceed not by dealing with an individual commissioner, but by speaking with some central office or director, who could then approach individual commissioners and negotiate the religious beliefs of commissioners "behind the scenes" so that no "no couple would be denied services because of a consideration which would engage s. 15 of the Charter" (ibid at para 85).

$82 \quad$ Ibid at para 92.

Ibid at para 100 . 
and lesbian people ${ }^{84}$ Four members of the public who received Whatcott's flyers at their homes complained to the Human Rights Commission, alleging that the material promoted hatred on the basis of sexual orientation contrary to section 14 of the Saskatchewan Human Rights Code ${ }^{85}$ Whatcott in response argued that section 14 of the Code infringed his Charter rights to freedom of expression and freedom of religion.

The Human Rights Tribunal concluded that section 14 of the Code constituted a reasonable restriction on Whatcott's Charter rights, and found the flyers he distributed breached section 14 because "certain passages from each of the flyers ... could objectively be viewed as exposing homosexuals to hatred and ridicule." ${ }^{" 86}$ The Saskatchewan Court of Queen's Bench upheld the Tribunal's conclusions ${ }^{87}$ The Court of Appeal concluded that Whatcott's flyers did not violate the Code because they were part of "ongoing debate about teaching homosexuality in public schools" and about sexual morality generally. The concurring opinion of Justice Smith found it of some significance in interpreting the context of Whatcott's flyers that they were directed at same-sex conduct, not same-sex orientation. ${ }^{88}$

The Supreme Court of Canada concluded that although the statutory prohibition on hate speech in section 14 of the Code infringed Whatcott's Charter rights to freedom of expression and freedom of religion, the limit was justified under section 1 . The Court began by situating this case as one where, "[g]iven the engagement of freedom of expression, freedom of religion and equality rights in the present context, a s.1 analysis is the appropriate procedural approach under which to evaluate their constitutional interplay." $" 89$ Adopting a broad reading of the religious interests at stake, the Court concluded that the prohibition on hate speech substantially interferes with Whatcott's ability to disseminate his sincerely held religious beliefs about homosexuality, infringing his Charter right to freedom of religion.

The Court then turned to section 1, classifying this as a case where, because "the manifestations of an individual's right or freedom are incompatible with the very values sought to be upheld in the process of undertaking a s.1 analysis ... an attenuated level of s.1 justification is appropriate. ${ }^{, 90}$ The Court identified the pressing and substantial objective of the Code prohibition on hate speech as "reducing the harmful effects and social costs of discrimination by tackling certain causes of discriminatory activity."91 The Court concluded that the inclusion in section 14 of speech that "ridicules, belittles or otherwise affronts the

The flyers were entitled "Keep Homosexuality of our Saskatoon's Public Schools!," "Sodomites in our Public Schools" and "Saskatchewan's largest gay magazine allows ads for men seeking boys!": see Whatcott, supra note 16 at Appendix B.

Saskatchewan Human Rights Code, SS 1979, c S-24.1, s14(1)(b) [Code] ("[n]o person shall publish or display ... any representation, including any notice... that exposes or tends to expose to hatred, ridicules, belittles or otherwise affronts the dignity or any person or class of persons on the basis of a prohibited ground").

Whatcott SCC, supra note 16 at para 10.

Whatcott v Human Rights Tribunal (Sask) et al, 2007 SKQB 450, 306 Sask R 186.

Whatcott $v$ Saskatchewan (Human Rights Tribunal), 2010 SKCA 26, 317 DLR (4th) 69 at paras 78, $131-32$.

Whatcott SCC, supra note 16 at para 154. The Court described its job under section 1 as follows:

We are therefore required to balance the fundamental values of freedom of expression (and, later,

freedom of religion) in the context in which they are invoked, with competing Charter rights and other values essential to a free and democratic society, in this case, a commitment to equality and respect for group identity and the inherent dignity owed to all human beings (ibid at para 66 [citations omitted] [emphasis in original]).

Whatcott SCC, supra note 16 at para 71. 
dignity of any person or class of 'persons on the basis of a prohibited ground"92 was not rationally connected to the objective of protecting people from the harms of hate speech because such speech, while repugnant, does not "seek to marginalize the group by affecting its social status and acceptance in the eyes of the majority." 93 That language was severed from section 14 of the Code.

The hate speech prohibition was minimally impairing of religious rights, and the benefits of the suppression of hate speech and its harmful effects outweighed the deleterious effects on restricting expression. That Whatcott's expression was religiously motivated was found to be of no consequence for determining whether it violated the hate speech prohibition in section 14 of the Code. Two of the flyers involved "representations that expose or are likely to expose the vulnerable group to detestation and vilification," $"$ and thus violated the Code.

\section{B. ShifTING APPROACHES TO EQUALITY AND RELIGION}

What do these four cases reveal about the implementation of the reconciliation framework in cases where equality based on sexual orientation and freedom of religion are in competition? Comparing the four decisions canvassed above reveals a number of insights about how appellate courts have conceptualized equality and religion in the context of competitions between these two rights, and how they understand the geography of the space where these two rights come into tension. Three observations are apt.

\section{ChangING CONCEPTIONS OF EQUALiTy}

In two of the cases above, the courts adopted thin versions of the Charter right to equality. In TWU SCC the Supreme Court characterized the equality issues at stake as "equality concerns of students in B.C.'s public school system, concerns that may be shared with their parents and society generally." 95 The language of "concerns" obscures the fact that constitutional rights are at stake in the case, and the conditional "may" positions equality as an optional issue on the facts of the case. Moreover, this framing fails to acknowledge that equality rights are "a mark of society's values," 96 not concerns possibly shared by a small interest group. Confirming this highly individualized view of equality, the analysis in TWU SCC focuses only on the question of whether TWU students who signed the Covenant would act in an overtly discriminatory manner in public school classrooms, neglecting to consider how BCCT approval of the Community Covenant results in symbolic and dignitary harms relevant to assessing the equality interests of GLBQ individuals in context, as well as broader harms to our collective ideals of equality and fair treatment. ${ }^{97}$ To the extent that the equality

$92 \quad$ Ibid at para 99.

93 Ibid at para 80. This is because the objective embodied in section 15(1) of the Charter of eliminating discrimination and ensuring substantive equality "generally focuses on reducing the perpetuation of prejudice and disadvantage to members of a group on the basis of statutorily enumerated (or analogous) personal characteristics, or on the perpetuation of stereotyping that does not correspond to the actual circumstances and characteristics of the claimant group" (ibid at para 79).

Ibid at para 163 .

TWU SCC, supra note 14 at para 28 [emphasis added].

Hughes, "Reconciliation," supra note 11 at 280

Ibid. Hughes notes that this shortcoming is puzzling given that the Supreme Court seems to understand the symbolic power of words in other contexts, including Butler, supra note 50 where the Court recognized women feel degraded as victims of the message of obscenity and Keegstra, supra note 39 (where the Court recognized the "emotional damage caused by words may be of grave psychological and social consequence" at para 64). 
of GLBQ people was infringed by the Covenant, it was simply "that they would probably not feel welcome at Trinity Western." $" 98$

In Chamberlain CA, the Court of Appeal was noticeably suspicious of the equality claims, and claimants, in the case. The Court of Appeal used the word "equality" only three times in its 38-page judgment, and only ever in reference to rights to religious equality, not the equality rights of GLBQ people or same-sex families. While appearing to recognize the importance of non-discrimination in the public school context, the Court in Chamberlain CA easily accepted, based on unspecified evidence, that in taking its decision to reject the books, the Board had acted in accordance with the directive on non-discrimination on the basis of sexual orientation issued by the Superintendent. It did not inquire into how or where the Board had weighed equality or non-discrimination in reaching its decision. Perhaps even more troubling, the Court rejected Chamberlain's argument that his purpose in introducing the impugned books was to demonstrate the "presence of nurturing values in alternative families generally" finding instead that the books were selected for their "sexual orientation dimension." "99 The Court admonished Chamberlain, stating that given that "sexual orientation issues raise strong emotions," he "must have known" that he was "inviting confrontation" in attempting to introduce the books. ${ }^{100}$ In both TWU SCC and Chamberlain CA the courts minimized the nature of the alleged equality violations.

Conversely, in Marriage Commissioners and Whatcott SCC, the courts enunciated relatively more robust visions of the equality dimensions of the cases. The courts expounded on the multifaceted harms of inequality and discrimination not only for individuals, but also for communities and society writ large. In describing the deleterious effects of a law allowing marriage commissioners to deny services to same-sex couples on the basis of personal religious belief in Marriage Commissioners, the Court of Appeal considered the "genuinely harmful impacts" 101 on the individuals denied marriage services, and on the "gay and lesbian community at large ... friends and families of gay and lesbian persons and the public as a whole."102 Additionally, the Court considered the concrete impact of the proposed amendments on the broader societal commitment to equality, finding that the proposed legislation "would be a significant step backward" for our "national community [which] has only recently begun to overcome" discrimination on the basis of sexual orientation. ${ }^{103}$

Similarly in Whatcott SCC, the Supreme Court identified the harmful effects of hate speech as accruing at the individual, group, and societal levels, finding that "[w]hen hate speech pertains to a vulnerable group, the concern is that it will perpetuate historical prejudice, disadvantage and stereotyping and result in social disharmony as well as harm to the rights of the vulnerable group." 104 In addition, the Court in Whatcott SCC implicitly rejected the majority position in TWU SCC, which, in characterizing the implications of TWU's Covenant, seemed to accord some importance to the fact that the Covenant "make[s]

Hughes, "Reconciliation," ibid; TWU SCC, supra note 14 (noting "a homosexual student would not be tempted to apply for admission, and could only sign the so-called student contract at a considerable personal cost" at para 25).

Chamberlain CA, supra note 13 at para 59.

Ibid at para 57.

Supra note 15 at para 95 .

Ibid at para 96.

Ibid at para 94.

Whatcott SCC, supra note 16 at para 79 . 
no reference to homosexuals or to sexual orientation, but only to practices that the particular student is asked to give up himself, or herself, while at TWU."105 Instead, the Court in Whatcott SCC adopted the insights of Justice L'Heureux-Dubé, dissenting in TWU SCC, who concluded that " $[\mathrm{t}]$ he status/conduct or identity/practice distinction for homosexuals and bisexuals should be soundly rejected." 106 The distinction between same-sex behaviour and sexual orientation was not sustainable because "[w] here the conduct that is the target of speech is a crucial aspect of the identity of the vulnerable group, attacks on this conduct stand as a proxy for attacks on the group itself.",107

Some may argue that part of the explanation for the diverse approaches to conceptualizing the equality rights of GLBQ people in TWU SCC, Chamberlain CA, Marriage Commissioners, and Whatcott SCC must be the significant social and political advancements made by the GLBQ rights movement over the past 15 years. Chamberlain SCC and TWU SCC were decided in 2000 and 2001, respectively, which was relatively early in the life of GLBQ rights litigation under the Charter. By contrast, the more recent opinions in Marriage Commissioners and Whatcott both occurred after the legalization of same-sex marriage in 2004, in a time when GLBQ rights are now more fully conceptualized and more readily understood and accepted by Canadian courts. It was possible in TWU SCC and Chamberlain $\mathrm{CA}$, for the courts to frame the challenges so as to minimize the equality interests at stake. While similar framings may have technically been available in the later cases of Marriage Commissioners and Whatcott SCC, the courts there took a notably different approach, consistent with the evolution in judicial approaches to equality based on sexual orientation that had occurred in the interim.

However, the differing social and political climates within which these decisions were taken cannot entirely justify the fact that the Supreme Court in TWU SCC and the Court of Appeal in Chamberlain CA adopted relatively impoverished views of the equality rights at stake: at the time those early decisions were made, the Supreme Court had repeatedly confirmed and expounded upon equality rights based on sexual orientation in foundational cases including Egan v. Canada, ${ }^{108}$ Vriend v. Alberta ${ }^{109}$ and M. v. H. ${ }^{110}$ The courts in TWU SCC and Chamberlain CA were operating within a legal context that expressly recognized discrimination based on sexual orientation. Accordingly, these two early cases may be read as symptomatic of the slipperiness of equality rights in moments where they are set against a more firmly defined fundamental freedom like religion.

\section{BROAD CONCEPTIONS OF RELIGIOUS RightS AND FREEDOMS}

In contrast to the narrow view of equality adopted in Chamberlain CA and TWU SCC, the Courts in those cases took a relatively robust view of the religious rights at stake, adopting an understanding of "religious expression [as] monolithic and, if protected, it cannot be 
curtailed ... to prevent the diminution of homosexual equality." "111 In Chamberlain CA, the Court of Appeal emphasized that "[m]oral positions must be accorded equal access to the public square without regard to religious influence" 112 finding that "[t]o interpret secular as mandating 'established unbelief' ... would effectively banish religion form the public square." 113 These statements suggest the Court's view that "any curtailment of religious expression is equal to a denial of religious protection" "114 writ large. To similar end, the majority in TWU SCC took an extremely broad view of religious belief and a narrow view of religiously-motivated actions. Based on its conclusion that "[ $\mathrm{t}]$ he freedom to hold beliefs is broader than the freedom to act on them," "115 the majority characterized the act of signing the TWU Covenant as "merely a belief that has no concrete discriminatory aspect or ... [as] an essentially meaningless formality." 116 This conclusion cast a very wide net for protected religious belief.

Marriage Commissioners maintained a "broad and protective approach"117 to religious freedom but evidences a decided shift away from the monolithic view apparent in the earlier decisions. For example, the Court of Appeal in Marriage Commissioners rejects the monolithic model of religion when it qualifies the salutary effects of the amendments, which would "allow marriage commissioners to avoid acting in situations which would offend their religious beliefs," 118 with the following statement:

[T] he freedom of religion interests [the amendments] accommodate do not lie at the heart of s. 2(a) of the Charter. In other words, the [amendments] are concerned only with the ability of marriage commissioners to act on their beliefs in the world at large. They do not in any way concern the freedom of commissioners to hold the religious beliefs they choose or to worship as they wish. This reality means the benefits flowing from the [amendments] are less significant than they might appear on the surface. ${ }^{119}$

This is a more nuanced, contextual reading of the religious freedoms at stake when compared to the earlier cases, and better accords with importance of context in scenarios requiring reconciliation. Similarly, in Whatcott SCC, the benefits of the suppression of hate speech and its harmful effects on equality outweighed the deleterious effects on restricting religiously motivated expression that exposes a vulnerable group to vilification and detestation in part because the religious expression "by its nature, does little to promote the values underlying freedom of expression" $" 120$ or freedom of religion.

Again, part of accounting for the differing approaches to conceptualizing the religious freedoms at stake in TWU SCC and Chamberlain CA and Marriage Commissioners and Whatcott SCC necessarily lies in the evolution in the section 2(a) jurisprudence over the

111 Bruce MacDougall, "A Respectful Distance: Appellate Courts Consider Religious Motivation of Public Figures in Homosexual Equality Discourse - The Cases of Chamberlain and Trinity Western University" (2002) 35:2 UBC L Rev 511 at 518.

Supra note 13 at para 28.

Ibid at para 30 .

MacDougall, supra note 111 at 521.

TWU SCC, supra note 14 at para 36

MacDougall, supra note 111 at 524.

Carissima Mathen, "What Religious Freedom Jurisprudence Reveals About Equality” (2011) 6:2 JL \& Equality 163 at 164 .

Supra note 15 at para 92.

Ibid at para 93.

Supra note 16 at para 148. 
relevant time period. However, the shift from the very broad, totalizing position on religion evident in the earlier cases to the still robust but considerably more context specific reading in Marriage Commissioners and Whatcott SCC suggests that courts are continuing to grapple with how to provide a vigorous interpretation of religious rights where those rights are in tension with equality.

\section{RECONCILING EQUALITY AND RELIGION}

The relatively narrow scope afforded equality and the singular approach to religious freedom adopted in Chamberlain CA and TWU SCC dictated the reconciling analyses that took place in the space of contestation between the two Charter rights. Bruce MacDougall, writing contemporaneously with these two cases, argued that the courts in both Chamberlain CA and TWU SCC proceeded from the premise that these cases were primarily "instances of assault on religion" ${ }^{121}$ as opposed to being about the equality rights of GLBQ people or about the need to reconcile competing Charter interests. ${ }^{122}$ Indeed in TWU SCC, the Court placed a heavy burden on the BCCT and those arguing from a position of equality, stating "the restriction on freedom of religion must be justified by evidence that the exercise of this freedom of religion will, in the circumstances of this case, have a detrimental impact on the school system." ${ }^{123}$ Likewise in Chamberlain CA, the bulk of the analysis was devoted to the proper place of religion and religiously motivated positions in school board decision making. Because the reconciliation exercise was framed from the perspective of the religious freedoms at stake, there was minimal engagement with the features of the specific conflict between religion and equality. ${ }^{124}$ One wonders if these cases can be properly understood as instances of reconciliation at all.

Another telling feature of the reconciliation exercise in both TWU SCC and Chamberlain CA is judicial reliance on the "choices" available to the equality claimants. Emphasizing choice seemed to operate as something of an escape hatch, allowing courts to avoid digging into the equality dimensions of the reconciliation exercise. In TWU SCC the Court stated: "we conclude that a homosexual student would not be tempted to apply for admission, and could only sign the so-called student contract at a considerable personal cost. TWU is not for everybody; it is designed to address the needs of people who share a number of religious convictions." 125 In other words, if GLBQ students can go elsewhere to pursue postsecondary education, their equality rights are not fundamentally at issue. In Chamberlain CA, the Court of Appeal undermined Chamberlain's assertion that his goal in introducing books depicting same-sex couples in his classroom was to "convey the message that parents of children in alternative family models generally love and care for their children equally as much as parents in stereotypically 'traditional' families" ${ }^{\text {"126 }}$ by pointing out that he could have demonstrated this same point by choosing other books portraying "non-traditional" families

\footnotetext{
121 MacDougall, supra note 111 at 520-21.

Ibid.

TWU SCC, supra note 14 at para 35.

MacDougall, supra note 111 (concluding that "[a]lthough courts have said there is no hierarchy of Charter protections, these cases tend to disprove that assertion" at 514).

Supra note 14 at para 25 [emphasis added].

Supra note 13 at para 55.
} 
in the heterosexual context. ${ }^{127}$ This lead the Court to conclude that in choosing the impugned books, Chamberlain must have been specifically trying to introduce contentious issues of sexual orientation into the classroom.

Marriage Commissioners rejected arguments that "choice" can meaningfully subvert an equality claim. There, the Court of Appeal heard arguments that same-sex couples turned away by a commissioner who does not solemnize same-sex marriages "will be able to easily contact another commissioner who will be prepared to proceed." "28 The Court described this argument as "inappropriately discount[ing] the importance of the impact on gay or lesbian couples of being told by a marriage commissioner that he or she will not solemnize a samesex union" and ignoring the reality that in northern and rural areas where only a few marriage commissioners are employed, it may be not in fact be easy to find another commissioner willing to go forward with the marriage. ${ }^{129}$ Choice was not an answer to the equality issues raised by the claimants, nor could it be used to avoid full engagement with the rights contest at issue. These four cases confirm the importance of framing and perspective in the spaces of rights in tension.

\section{RECONCILING EQUALITY?}

The four cases examined above are revelatory for what they suggest about varying judicial approaches to balancing equality and religion in the context of competing rights. Perhaps the most apparent conclusion to be drawn from the analysis above is that it is only when both individual rights are robustly conceptualized in the circumstances of a given case that courts can meaningfully engage in reconciliation. It may be tempting to understand the developments in the jurisprudence of equality and religion in tension considered above as a simple "role reversal" — that is, in Chamberlain SCC and TWU SCC religion overdetermined the analysis, and in the Marriage Commissioners and Whatcott SCC, the pendulum swung in the other direction and equality assumed the more dominant conceptual role. In my view, a more accurate framing is that in the later cases equality found a more equal footing with religion in the context of rights in tension scenarios: both rights are more fully engaged in the later cases. At very least, these cases confirm that judicial efforts to reconcile equality with other rights "must plunge ... into this question of the proper scope of the demands made by equality" $" 130$ and religion alike.

Plunging into these demands is rarely a simple task, particularly with respect to equality. Equality is an inherently slippery concept, and judicial approaches to section 15 are

Ibid, stating:

Some of the "alternative" families obviously will involve more than one father or more than one mother in heterosexual contexts. For example it is not uncommon for a grandmother or aunt to take on a surrogate mother role for a birth mother. The children may well regard both women as mothers in such circumstances. In many families a mother may have separated from the birth father and formed a new relationship taking the children with her but allowing access to the birth father. In that situation the children might easily consider themselves to have two fathers (at para 56).

Ibid at paras 41-43.

Brown, supra note 28 at 30. 
notoriously in flux. ${ }^{131}$ Because equality is amorphous, it is susceptible to a range of possible framings and definitions. The equality interests at stake in a given context may be understood in a more or less robust fashion, as the cases above demonstrate. The inherent malleability of equality may be contrasted with the more clearly defined dimensions of religious freedom. Indeed, as Carissima Mathen has observed, "it seems to be easier for court to 'get' religious freedom claims than equality claims despite their frequent points of analytical intersection." 132 While courts have taken a "highly formalized approach to equality rights" rendering section 15 "an unstable platform for equality litigation," 133 the jurisprudence of religious freedom consistently engages "powerful purposive descriptions of the right that are supported...by the resulting analysis." "134 Where equality is minimized or defined narrowly on the facts of a given case, as with the early religion-equality cases canvassed above, the more readily identifiable, concretely defined religious interests are bound to succeed. Where equality is cognizable as a tangible interest, understood in a purposive fashion, as in the contemporary cases, there is the likelihood for reconciliation to occur.

The challenge then, is how to ensure a purposive conceptualization of equality notwithstanding its unstable foundations in rights in tension scenarios. While Marriage Commissioners and Whatcott SCC suggest a meaningful move toward more robust engagement with equality rights in the context of rights in tension, courts must continue to "plunge" into the equality interests at stake when equality competes with religion. Given the ongoing conceptual uncertainty in the jurisprudence of section 15 of the Charter, equality continues to be at risk of being minimized, marginalized, or sidelined in the reconciliation exercise when it comes into conflict with a relatively better-defined fundamental freedom like religion. The reality of these risks is obvious in Chamberlain SCC and TWU SCC. Courts must be attentive to the varying applications of the principles of reconciliation across different rights frameworks. For example, the existence of a "core-periphery" metric through which to specifically situate the degree of infringement of a religious right finds no parallel in equality jurisprudence. This means it could be more difficult for courts to calibrate the seriousness of an equality infringement in rights in tension scenarios. ${ }^{135}$

See for example the evolution of section 15 jurisprudence from the Supreme Court's foundational decision in Andrews $v$ Law Society of British Columbia, [1989] 1 SCR 143 [Andrews], to its muchcritiqued dignity-based framework of analysis in Law $v$ Canada (Minister of Employment and Immigration), [1999] 1 SCR 497, to its return to a simplified Andrews-esque model in $R v$ Kapp, 2008 SCC 41, [2008] 2 SCR 483. For useful commentary on the conceptual ambiguity and analytical difficulties of section 15 of the Charter: see e.g. Jennifer Koshan \& Jonnette Watson Hamilton, "The Continual Reinvention of Section 15 of the Charter" (2013) 64 UNBLJ 19; Sophia Moreau, "R. v. Kapp: New Directions for Section 15" (2008) 40:2 Ottawa L Rev 283; Diana Majury, "Equality Kapped; Media Unleashed" (2009) 27:1 Windsor YB Access Just 1; Patricia Hughes, "Resiling from Reconciling? Musing on R. v. Kapp" (2009) 47 SCLR (2d) 255; Jonnette Watson Hamilton \& Jennifer Koshan, "Meaningless Mantra: Substantive Equality after Withler" (2011) 16:1 Rev Const Stud 31.

Mathen, supra note 117 at 163-64.

Ibid at 164 .

Ibid.

See also Ontario (Human Rights Commission) v Brockie, (2002), 222 DLR (4th) 174 at at paras 51-56 (Ont Sup Ct J) where the Ontario Superior Court of Justice was faced with a contest between the religious freedom of Brockie, the owner of a printing company, and the equality rights of Brillinger. Brockie refused to accept Brillinger's order to print letterhead for the Gay and Lesbian Archives, saying that to do so would violate his religious freedoms as a Christian because by printing the letterhead he would be assisting in the dissemination of information intended to promote acceptance of a gay and lesbian "lifestyle," which Brockie believed was a sin. The Court agreed that Brockie's rights were infringed, but concluded, "Mr. Brockie's exercise of his right of freedom of religion in the commercial marketplace is, at best, at the fringes of that right" (at para 54). As a result, Brockie's freedom of religion had to give way to Mr. Brillinger's equality interests in this context. The Court in Brockie left open the possibility that core religious beliefs could be unjustifiably infringed in the commercial context if a 
The cases canvassed above demonstrate the importance of considering, in the space of contestation where two Charter rights appear to collide, the impacts of each claim on the other. According to Hughes, this includes being attentive to whether a claim "is premised on denying the equality of others, that is, that the basis for the claim reflects beliefs that some people are not equal." ${ }^{136}$ For example, in the Marriage Commissioners case, the "desire [of same-sex couples] to be married is not premised on forcing others to renounce their religious views, while the refusal of someone to marry them on the basis of religious views is premised on the denial of their equality rights. ${ }^{137}$ Attention to circumstances where the basis for a freedom of religion claim is that some people are not equal may help to ensure that equality rights are not minimized in the reconciliation exercise.

Indeed, the minimizing of equality rights remains a live risk in contemporary contests between religious freedoms and equality, as illustrated in the recent decision of the Nova Scotia Supreme Court in NSBS. ${ }^{138}$ In June 2012, TWU proposed a law school to the British Columbia Ministry of Advanced Education and the Federation of Law Societies of Canada. ${ }^{139}$ TWU requires its students, faculty and staff to sign a mandatory Community Covenant promising to abstain from same-sex intimacy. ${ }^{140}$ The Federation of Law Societies of Canada and the Minister of Advanced Education granted approval to TWU's proposed school of law in December 2013, ${ }^{141}$ and each of the individual law societies then undertook to determine whether to recognize a law degree from TWU for the purposes of admission to their

printing project "contained material that conveyed a message proselytizing and promoting the gay and lesbian lifestyle or ridiculed his religious beliefs, such material might reasonably be held to be in direct conflict with the core elements of Mr. Brockie's religious beliefs" (at para 56).

Hughes, "Reconciliation," supra note 11 at 282.

Ibid at 283 [emphasis in original].

Supra note 18.

Trinity Western University, "Proposed School of Law: Trinity Western University School of Law," online: <http://www.twu.ca/academics/school-of-law/>.

"Covenant," supra note 12. The Covenant expands on the general directive to abstain from same-sex intimacy in the following terms:

[A]ccording to the Bible, sexual intimacy is reserved for marriage between one man and one woman, and within that marriage bond it is God's intention that it be enjoyed as a means for marital intimacy and procreation. Honouring and upholding these principles, members of the TWU community strive for purity of thought and relationship, respectful modesty, personal responsibility for actions taken, and avoidance of contexts where temptation to compromise would be particularly strong (ibid at 4 [footnotes omitted]).

For positions on both sides of the debate about TWU's law school: see e.g. Elaine Craig, "The Case for the Federation of Law Societies Rejecting Trinity Western University's Proposed Law Degree Program" (2013) 25:1 CJWL 148 [Craig, "Proposed Law Degree Program"]; Angela Cameron et al, "Trinity Western University - Discrimination on campus," National Post (20 December 2013), online: <full comment.nationalpost.com/2013/12/20/trinity-western-university-discrimination-on-campus/>; Dwight Newman, "On the Trinity Western University Controversy: An Argument for a Christian Law School in Canada" (2013) 22:3 Const Forum Const 1; Faisal Bhabha, "Let TWU Have Its Law School" (24 January 2014), Slaw (blog), online: <www.slaw.ca/2014/01/24/let-twu-have-its-law-school/>.

Canadian Common Law Program Approval Committee, Report on Trinity Western University's Proposed School of Law Program (Ottawa: Federation of Law Societies of Canada, December 2013), online: <docs.flsc.ca/ApprovalCommitteeFINAL.pdf>; Special Advisory Committee on Trinity Western's Proposed School of Law, Final Report (Ottawa: Federation of Law Societies of Canada, December 2013), online: <docs.flsc.ca/SpecialAdvisoryReportFinal.pdf>; British Columbia Ministry of Advanced Education, "Statement on Trinity Western University's proposed law degree" (Victoria: BCMAE, 18 December 2014), online: <www2.news.gov.bc.ca/news_releases_2013-2017/2013AVED 0047-001903.htm>. 
provincial or territorial bars. ${ }^{142}$ The Charter binds the discretionary decision-making of all law societies. ${ }^{143}$

The processes and outcomes across jurisdictions have varied widely. ${ }^{144}$ The Council of the Nova Scotia Barristers' Society (NSBS) invited public submissions ${ }^{145}$ and voted $10-9$ to adopt a motion stating in part:

[The TWU] Community Covenant is discriminatory and therefore Council does not approve the proposed law school at Trinity Western University unless TWU either:

i) exempts law students from signing the Community Covenant; or

ii) amends the Community Covenant for law students in a way that ceases to discriminate. ${ }^{146}$

The Law Society of Upper Canada and the British Columbia Law Society also elected not to accredit TWU's proposed law school. ${ }^{147}$ TWU and Brayden Volkenant, a TWU graduate who hopes to attend the proposed law school, then sought judicial review of the three decisions not to accredit the proposed law school.

The Nova Scotia case was the first to proceed, and in January 2015, the Supreme Court of Nova Scotia issued a 139-page decision in favour of TWU. Justice Jamie Campbell found,

Each province and territory has constitutional jurisdiction over its own members. In Ontario, for example, the Law Society of Upper Canada has the power to decide whether to accredit TWU's law school pursuant to section 27(1) of the Law Society Act, RSO 1990, c L.8, which provides:

The classes of licence that may be issued under this Act, the scope of activities authorized under

each class of licence and any terms, conditions, limitations or restrictions imposed on each class

of licence shall be as set out in the by-laws.

By-law No 4, Licensing, s 9 makes it a general condition of licensing that an applicant have a degree from an "accredited law school," which is defined in section 7 of the bylaw as "a law school in Canada that is accredited by the Society" (By-law No 4, Licensing, s 7).

143 See e.g. Doré v Barreau du Quebec, 2012 SCC 12, [2012] 1 SCR 395 (a unanimous Supreme Court confirmed that "administrative decisions are always required to consider fundamental values.... [A]dministrative bodies are empowered, and indeed required, to consider Charter values within their scope of expertise" at para 35). On equality as a Charter value in the post-Doré context: see e.g. Angela Cameron \& Paul Daly, "Furthering Substantive Equality Through Administrative Law: Charter Values in Education" (2013) 63 SCLR (2d) 169.

The law societies of Alberta, Saskatchewan, and Prince Edward Island elected to accredit TWU; see e.g. Law Society of Alberta, Bulletin (14 January 2014), online: $<$ www.lawsociety.ab.ca/docs/default-source/ bulletins/bulletin_2014_01jan_14_no1.htm>. The law societies of Newfoundland and Labrador and Manitoba opted to monitor the ongoing debate and have deferred their individual determinations to a later date: see e.g. Law Society of Manitoba, "Trinity Western University Decision," online: $<$ www.lawsociety.mb.ca/news/trinity-western-university-decision>; Law Society of Newfoundland \& Labrador, "Law Society Response - Trinity Western University's Proposed Law School" (11 June 2014), online: <www.lawsociety.nf.ca/law-society-response-trinity-western-universitys-proposed-lawschool/s.

145 Nova Scotia Barristers' Society, "TWU public input," online: $<$ nsbs.org/twu-public-input>. Nova Scotia Barristers' Society, "Council votes for option C in Trinity Western Law School decision," online: $<$ nsbs.org/news/2014/04/council-votes-option-c-trinity-western-university-law-school-decision> Following outcry from lawyers over its initial decision to accredit TWU, British Columbia held a special general meeting that resulted in the revocation of the approval: Law Society of British Columbia, Trinity Western University: proposed law school," online: $<$ www.lawsociety.bc.ca/page.cfm?cid=3912 $>$. See also Andrea Woo, "In binding referendum, B.C. lawyers vote not to approve Trinity Western law school," Globe \& Mail (30 October 2014), online: <www.theglobeandmail.com/news/british-columbia/ in-binding-referendum-bc-lawyers-vote-not-to-approve-trinity-western-law-school/article21396188/>. Following this decision, the British Columbia Minister of Advanced Education revoked his prior approval of the proposed law school: British Columbia, News Release "Statement on Trinity Western University's school of law" (11 December 2014), online: <www.newsroom.gov.bc.ca/2014/12/ statement-on-trinity-western-universitys-school-of-law.html $>$. 
first, that the NSBS did not have the authority to require TWU to change its Covenant in order to receive accreditation, concluding, "[t] he extent to which NSBS members or members of the community are outraged or suffer minority stress because of the law school's policies does not amount to a grant of jurisdiction over the university." 148 Second, Justice Campbell held that even if the NSBS did have the authority to make such a determination, the way that it exercised its discretion in deciding not to accredit TWU failed to give appropriate consideration to the religious freedoms of the TWU community. Addressing arguments that the NSBS decision was made in "an effort to uphold the equality rights of LGBT people," 149 Justice Campbell stated:

\begin{abstract}
It was not an exercise of anyone's equality rights. It was the decision of an entity acting on behalf of the state purporting to give force and voice to those rights. The NSBS is not the institutional embodiment of equality rights for LGBT people. To justify an infringement of religious liberty the NSBS action has to be directed at achieving something of significance. Refusing a TWU law degree will not address discrimination against anyone in Nova Scotia. ${ }^{150}$
\end{abstract}

A full analysis of the reasons of the Nova Scotia Supreme Court is beyond the scope of the present inquiry. However, the decision confirms a number of the insights about reconciling equality and religious freedoms from the foregoing analysis, and is illustrative of some of the ongoing risks to the slippery ideal of equality in rights in tension scenarios.

First, the decision of the Nova Scotia Supreme Court begins by framing the case in a particular manner, with the statement: “[t]his decision isn't about whether LGBT equality rights are more or less important that the religious freedoms of Evangelical Christians. It's not a value judgment in that sense at all." ${ }^{151}$ Given that the decision of the NSBS not to accredit TWU was made expressly on the basis of concerns about the discriminatory nature of the TWU Covenant, how could this case be about anything but the reconciliation of equality and religion? ${ }^{152}$ According to the framing provided by Justice Campbell, the issue is whether "the NSBS reasonably considered the implications of its actions on the religious freedoms of TWU and its students in a way that was consistent with Canadian legal values of inclusiveness, pluralism and the respect for the rule of law."153 Justice Campbell's approach defines the case as outside the rights in tension framework and proceeds from a starting point focused exclusively on religious rights. This standpoint is reminiscent of the TWU and Chamberlain cases, above, and sets the stage for a "lopsided" analysis that undermines and minimizes equality rights. ${ }^{154}$

Second, the decision reflects a near-total failure to acknowledge the concrete equality interests at stake in the context of the case. Despite arguments and expert evidence about the

NSBS, supra note 18 at para 8.

Ibid at para 12 .

Ibid.

Ibid at para 3.

Ibid (where Justice Campbell characterizes the decision of NSBS as one of optics, not the realities of discrimination, finding that the case is "about the public perception of accepting an otherwise acceptable law degree from TWU" because of concerns by the NSBS about being seen to be "condoning discrimination" at para 194).

Ibid at para 3 .

Elaine Craig, "Trinity Western ruling lopsided in favour of religious rights" The Chronicle Herald (3 February 2015), online: <thechronicleherald.ca/opinion/1267048-trinity-western-ruling-lopsided-infavour-of-religious-rights $>$ [Craig, "Trinity Western"]. 
specific harms to GLBQ individuals and the broader community bred by exclusionary policies like the TWU Covenant, ${ }^{155}$ the judgment of the Nova Scotia Supreme Court reduces the equality dimensions of the case to "outrage, [a] sense of emotional pain, minority stress or hurt feelings." 156 This characterization minimizes the realities of discrimination, and individualizes the equality issues as relegated to the "hurt feelings" of some GLBQ individuals:

There is no evidence beyond speculation that LBGT people in Nova Scotia are harmed in any way, however slight, by living in the knowledge that an institution in Langley British Columbia, which ... does not recognize same sex marriage but which properly educates lawyers who can practice law in Nova Scotia, where discrimination within the profession is strictly forbidden. ${ }^{157}$

Justice Campbell's conclusion neglects the adverse impacts that public approval by NSBS of an institution that discriminates against GLBQ people would have on our broader societal commitment to equality, acknowledged in Whatcott SCC, above. According to Justice Campbell, the NSBS decision not to accredit TWU was primarily motivated by political optics and "does nothing to protect the equality interests of LGBT people." 158 This particular conceptualization of the equality dimensions of the case is so thin as to render equality practically non-existent for the purposes of the analysis. As in the 2001 TWU SCC case, any apparent tension between religion and equality is defined out of existence by the diminution of equality. ${ }^{159}$

Finally, from a purely jurisprudential perspective, equality as a Charter right is virtually absent from the analysis. Justice Campbell cites no case law on the nature and scope of equality rights under section 15 of the Charter, nor does he engage with the Supreme Court's extensive body of precedent on the specifics of equality violations based on sexual orientation. Confirming the asymmetry inherent in the analysis, Justice Campbell cites a long lineage of Supreme Court case law, including Syndicat Northcrest v. Amselem, ${ }^{160}$ Multani, ${ }^{161}$ S.L. v. Commission scolaire des Chênes, ${ }^{162}$ and $N S,{ }^{163}$ that confirms a "broad and expansive" 164 approach to religious freedoms under the Charter. Justice Campbell finds the religious freedom case law to be "quite a far cry from the kind of development by which secular concerns and equality rights have expanded so that there is little or no room for religious freedom and freedom of religious expression that offends those values."165

NSBS, supra note 18 at paras 90, 104, 106-107.

Ibid at para 180 .

Ibid at para 254. Others have noted that Justice Campbell's statements about GLBQ equality are deeply problematic: see e.g. Craig, "Trinity Western," supra note 154.

Ibid at para 264.

Justice Campbell confirms that TWU SCC is a precedent with ongoing relevance, notwithstanding arguments that the legal and social landscapes have changed significantly since that decision in 2001, concluding: "[t]he decision in TWU [SCC] has not been overtaken by other developments and is not an expression of outdated concepts involving the intersection of rights" (ibid at para 207). For detailed analysis on why the TWU SCC case is distinguishable from the context of the current scenario, see Craig, "Proposed Law Degree Program," supra note 140.

2004 SCC 47, [2004] 2 SCR 551 [Amselem].

Supra note 36.

2012 SCC 7, [2012] 1 SCR 235.

Supra note 5.

NSBS, supra note 18 at para 197 citing Amselem, supra note 160 at para 62.

NSBS, ibid at para 207. 
To the extent that equality does appear in the judgment in a meaningful way, it is in the context of repeated assertions discounting the idea that equality rights are some kind of trump card over religious rights and freedoms. Despite canvassing only the jurisprudence on religious rights and minimizing equality rights in the context of this case to "hurt feelings," the judgment concludes: "Equality rights have not jumped the queue to now trump religious freedom.... Religious freedom has not been relegated to a judicial nod to the toleration of cultural eccentricities that don't offend the dominant social consensus."166 This is as close to any kind of engagement with the reconciliation or balancing exercise as the judgment gets.

\section{Conclusion}

In Vriend, one of the earliest cases on equality rights of GLBQ people, Justice Cory described equality as "the foundation for a just society," with section 15 of the Charter reflecting the "fondest dreams, the highest hopes and finest aspirations of Canadian society." ${ }^{167}$ The analysis above considered evolving judicial approaches to rights in tension cases involving the equality rights of GLBQ people and freedom of religion under the Charter, comparing four appellate-level cases from the past 15 years to illustrate the various ways that courts are conceptualizing religion, equality, and the conflict between the two. I suggested that the reconciliation exercise poses specific risks to the often hard-to-define right to equality when it comes up against a relatively better-defined Charter right like freedom of religion, and emphasized the need to maintain a broad and purposive approach to defining equality as a concrete interest in rights in tension scenarios, notwithstanding ongoing conceptual ambiguity about the nature and scope of the equality ideal under section 15 of the Charter. Finally, the paper considered the recent decision of the Nova Scotia Supreme Court in Trinity Western University v. Nova Scotia Barristers' Society as indicative of the ongoing risks to the equality rights of GLBQ people in rights in tension cases. 